\title{
Leaf anatomy of the South African Danthonieae (Poaceae): XIX. The genus Prionanthium
}

\author{
R.P. ELLIS*
}

Keywords: Arundineae, leaf anatomy, linear glands, Poaceae, Prionanthium, taxonomy

\section{ABSTRACT}

The leaf blade anatomy of Prionanthium dentatum (L. f.) Henr., P. ecklonii (Nees) Stapf and P. pholiuroides Stapf is described and illustrated. The transectional anatomy is non-Kranz with diffuse chlorenchyma. The adaxial epidermis has dome-shaped stomata, dumbbell-shaped to nodular silica bodies and elongated microhairs. The three species differ in the presence or absence of macrohairs, abaxial stomata and marginal linear, sessile glands. The latter character is shared with Pentaschistis triseta (Thunb.) Stapf and its allies, and relationships with Pentaschistis are indicated rather than with any other extant arundinoid genus.

\section{UITTREKSEL}

Die blaaranatomie van Prionanthium dentatum (L. f.) Henr., P. ecklonii (Nees) Stapf en $P$ pholiuroides Stapf word beskryf en geillustreer. Die anatomie in dwarssnee is nie-Kranz met eweredig verspreide chlorenchiem. Die abaksiale epidermis het koepelvormige huidmondjies, murgbeenvormige silikaliggaampies en langwerpige, vingeragtige mikrohare. Die drie spesies verskil ten opsigte van die voorkoms van makrohare met geen gespesialiseerde basale epidermisselle, abaksiale huidmondjies en lineêre, steellose kliere op die blaarrand. Soortgelyke kliere kom ook by Pentaschistis triseta (Thunb.) Stapf en sy verwante spesies voor en verwantskappe met Pentaschistis word aangedui, eerder as met enige ander teenwoordigers van die tribus Arundineae.

\section{INTRODUCTION}

The genus Prionanthium is a small genus of three species all endemic to the south-western Cape Province. It includes small, ephemeral or annual plants which are exceedingly difficult to locate and are considered to be rare and/or endangered (Davidse 1988). Taxonomically the genus does not pose any particular difficulties and it contains three morphologically distinct species: $P$. dentatum (L. f.) Henr. (= $P$. rigidum Desv.), $P$. ecklonii (Nees) Stapf and $P$. pholiuroides Stapf. These three species are recognized by most previous workers (Chippindall 1955; Clayton \& Renvoize 1986; Watson et al. 1986; Davidse 1988) although all these workers did not have access to material of all three taxa.

The recent revision by Davidse (1988) included all the anatomical voucher specimens used for the present study and the anatomical data reported on here is complementary to the morphology and cytology discussed in this revision. The present study is the first in which comparative leaf anatomy of all three species has been undertaken.

Although there is little difficulty with the delimitation of taxa within Prionanthium, the generic relationships of the genus are puzzling. Most authors now agree with the placement of the genus in the Arundinoideae, usually in the tribe Arundineae (= Danthonieae). Davidse (1988) convincingly argues the case for arundinoid relationships and, furthermore, demonstrates that Prionanthium and Pentaschistis are probably related. This conflicts with the suggestion of Clayton \& Renvoize (1986) that the genus

\footnotetext{
* Botanical Research Institute. Department of Agriculture and Water Supply, Private Bag X101, Pretoria 0001

MS. received: 1989.02 .15
}

belongs with the primitive arundinoid genera such as Tribolium, Urochlaena, Elytrophorus and others from Australasia. The phylogenetic implications of the leaf anatomy of Prionanthium will be considered in this paper in order to shed more light on this problem. The purpose of this paper is, therefore, to describe and illustrate the leaf blade anatomy of Prionanthium and to compare this structure with that of the other South African danthonioid species, as well as with earlier published results for Prionanthium.

Little detailed attention has been given to the leaf anatomy of Prionanthium in the published literature but the information available does indicate typical arundinoid anatomy. The anatomy is non-Kranz with a double bundle sheath, non-radiate mesophyll with a maximum lateral cell count greater than four, bulliform cell groups not associated with colourless cells, finger-like microhairs with tapering distal cells, domed subsidiary cells and dumbbell-shaped to nodular silica bodies (Hansen \& Potztal 1954; Renvoize 1986; Watson et al. 1986). Renvoize (1986) notes two unusual features for the subfamily: the chlorenchyma is not interrupted by sclerenchyma girders above and below the vascular bundles, and the epidermal cells are large and thin-walled. De Wet (1956) notes that the epidermis of Prionanthium is panicoid (with linear microhairs) but that the anatomy is festucoid with the chlorophyll tissue being uniformly distributed between the bundles.

\section{MATERIALS AND METHODS}

Specimens of all three species of Prionanthium were collected in the south-western Cape. Herbarium voucher specimens were prepared for verification by the staff of the National Herbarium (PRE) where they are housed. 


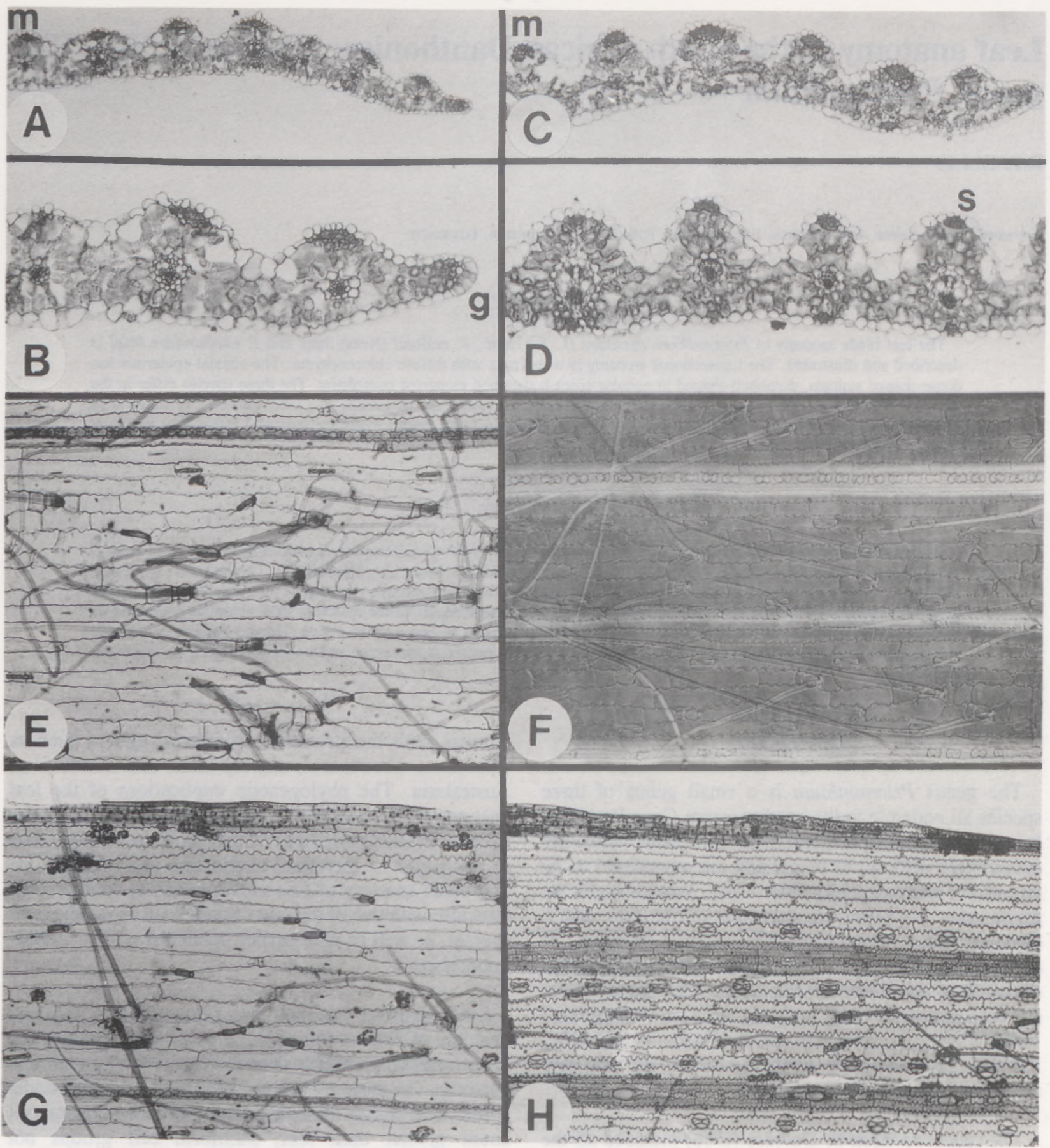

FIGURE 1. - Leaf blade anatomy of Prionanthium dentatum. A-D, leaf in transverse section: A, outline of lateral part of lamina showing undifferentiated midrib $(\mathrm{m})$ and narrow, projecting margin, $\times 100$; B, detail of margin showing sessile gland cells $(\mathrm{g})$ in the extreme margin and the diffuse nature of the chlorenchyma, $\times 250$; C, outline of lateral part of blade without midrib $(\mathrm{m})$ and with tapering margin, $\times 160$; D, anatomical detail of chlorenchyma, vascular bundles, adaxial ribs and sclerenchyma strands $(\mathrm{s}), \times 250$. E-H, abaxial epidermal structure as seen in surface view: E, macrohairs with single modified basal cell, microhairs and nodular silica bodies, $x$. 250; F, interference contrast of macrohairs and silica bodies, $\times 250$; G, lateral part of leaf blade with glandular marginal cells with persistent nuclei, $\times 250 ; \mathrm{H}$, sessile linear gland in leaf margin, $\times 250$. A, B, G, Ellis 5416; C, F, Ellis 2452; D, H, Ellis 5773; E, Ellis 5417.

These same specimens were also examined by Davidse for a revision of the genus (Davidse 1988).

Central segments of leaf blades were removed and immediately fixed in FAA. Transverse sections and epidermal scrapes of these blade segments were prepared following the methods outlined in previous papers in this series (e.g. Ellis 1988).

The standardized terminology of Ellis $(1976,1979)$ was used for the anatomical descriptions. The following abbreviations are used in the descriptions:

\author{
$\mathrm{vb} / \mathrm{s}$ - vascular bundle/s \\ 1 'vb/s - first order vascular bundle/s \\ 2 'vb/s - second order vascular bundle/s \\ $3^{\prime} \mathrm{vb} / \mathrm{s}$ - third order vascular bundle/s \\ ibs - inner bundle sheath; mestome sheath \\ obs - outer bundle sheath; parenchyma sheath
}

\section{Specimens examined}

\section{Prionanthium dentatum}

CAPE. - 3119 (Calvinia): 15-16 km SE of Nieuwoudtville on Oorlogskloof road to Clanwilliam (-AC), Ellis 2452 (16.10.1975), 5416, 5417 (20.9.1987), 5773 (11.10.1988). 


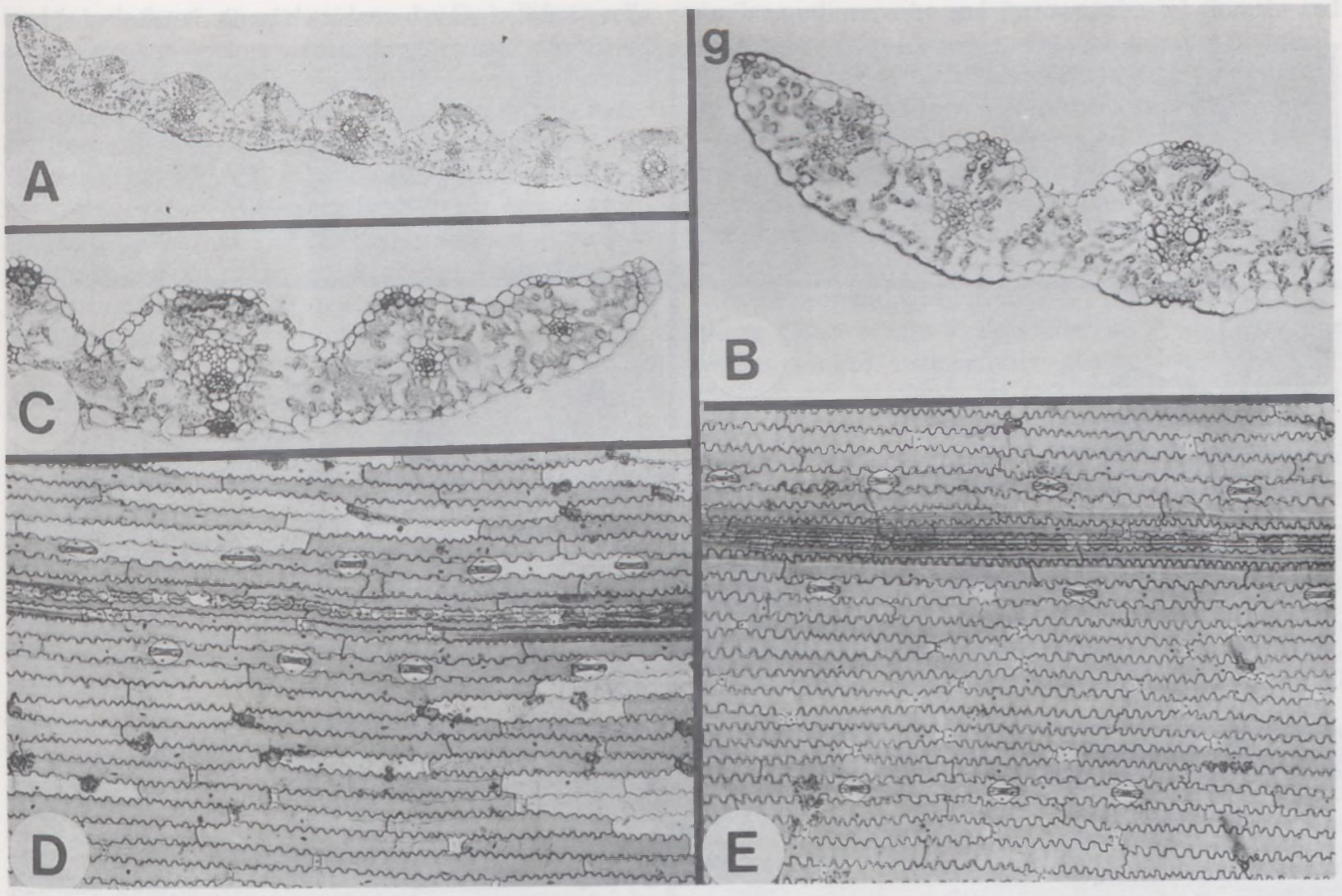

FIGURE 2. - Leaf anatomy of Prionanthium ecklonii, Davidse 34018. A-C, leaf in transection: A, outline with undifferentiated midrib and adaxial ribs, $\times 100$; B, detail of gently tapering left hand margin with few glandular cells in extreme margin $(\mathrm{g}), \times 250 ; \mathrm{C}$, detail of other margin, also with slightly enlarged epidermal cells constituting a sessile gland, $\times 250$. E-F, abaxial epidermal surface anatomy: $\mathrm{E}$, detail of sinuous intercostal long cells, dome-shaped subsidiary cells, microhairs and silica bodies, $\times 250$; F, long cell, stomata, silica body and microhair structure, $\times 250$.

\section{Prionanthium ecklonii}

CAPE. - 3218 (Clanwilliam): $45 \mathrm{~km} \mathrm{~N}$ of Citrusdal (-BD), Davidse 34018, Ellis 5784.

\section{Prionanthium pholiuroides}

CAPE. - 3318 (Cape Town): Darling Dist., 3 km E of Mamre Road, Rondevlei Farm (-BC), Ellis 5433, 5434, 5435. 3420 (Bredasdorp): 6 km N of Struisbaai (-CA), Davidse 34053.

\section{LEAF ANATOMY OF THE GENUS PRIONANTHIUM}

\section{Leaf blade in transverse section}

Outline: open, expanded, flat in $P$. dentatum and $P$. ecklonii (Figures 1A, C; 2A) but slightly inrolled to infolded in P. pholiuroides (Figure 3A, C, G). Ribs and furrows: medium to deep, open to narrow and cleft-like furrows present between all vbs. Similar rounded adaxial ribs associated with all vbs (Figures $1 \mathrm{~A}-\mathrm{D} ; 2 \mathrm{~A}-\mathrm{C}$; $3 A-D, G)$. No abaxial ribs or furrows but slight undulations may be associated with the vbs (Figure 2A). Median vascular bundle: not structurally distinct from lateral l'vbs. Vascular bundle arrangement: tends to vary across the lamina width with more 3'vbs between successive l'vbs in the region of the median bundle than laterally; 3 (P. ecklonii) or 2 ( $P$. dentatum and $P$. pholiuroides) 3'vbs between consecutive l'vbs in region of median bundle but only 1 laterally in all species; 3 ( $P$. pholiuroides), 5 (P. ecklonii and $P$. dentatum) and rarely 7 (P. dentatum) l'vbs in leaf section. No 2'vbs. All vbs located in centre of blade. Vascular bundle description: 3'vbs elliptical with xylem and phloem distinguishable. l'vbs round to elliptical in shape, phloem adjoins the ibs, metaxylem vessels very narrow with diameters much less than those of the obs cells (Figures 1B, D; 2B, C; 3B, D) with thin walls. Vascular bundle sheaths: double; round to slightly elliptical; obs often incomplete, particularly abaxially (Figure 3B, D, G); no extensions; obs cells inflated, rounded, the cells smaller than the chlorenchyma cells; walls thin; without chloroplasts or with few, small chloroplasts; ibs entire around all bundles; of small lignified cells with inner tangential and radial walls thickened. Sclerenchyma: adaxial sclerenchyma in the form of strands, either minute (Figure 2B, C), small (Figure 1B, D; 3B, D) or conspicuous (Figure 3G) in the Struisbaai population of $P$. pholiuroides; abaxial strands smaller and often not developed in association with the 3'vbs (Figure 3B, D, G). Fibres not lignified. Minute cap in margin but margin distinctly tapering in $P$. dentatum and $P$. ecklonii but not $P$. pholiuroides. No sclerenchyma present between bundles. Chlorenchyma: irregular, with no pattern in the cell arrangement; cells of different size and shape with conspicuous intercellular air spaces; occupy the entire area between the adaxial and abaxial epidermides, even the space above and below the vbs (Figures 1B, D; 2B, C; 3B, D, G); no arm cells or fusoids. Colourless cells: absent. Adaxial epidermal cells: small to medium-sized bulliform groups at bases of furrows in $P$. dentatum and $P$. ecklonii (Figures 1B, D; 2B, C), occupy less than $1 / 4$ leaf thickness, may be completely absent as in $P$. pholiuroides (Figure 3B, G); cuticle thin; epidermal appendages absent; no papillae although epidermal cells 


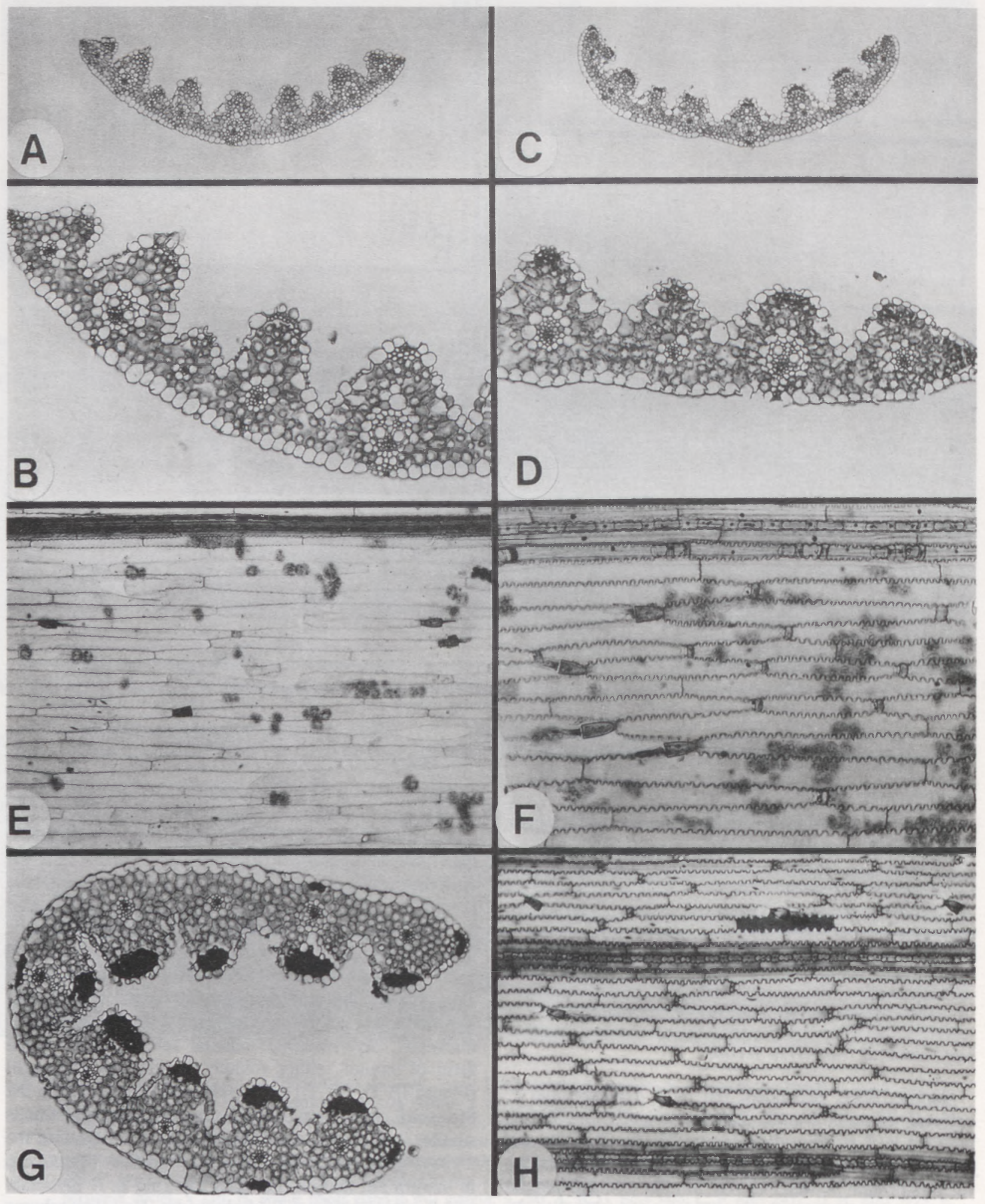

FIGURE 3. - Leaf anatomy of Prionanthium pholiuroides. A-F, specimens from the Mamre Road population. A-D, leaf blade transections: A, leaf outline showing vascular bundle arrangement and median vascular bundle not structurally differentiated from first order bundles, $\times 100$; B, detail of leaf margin with no sessile linear gland cells, $\times 250 ; \mathrm{C}$, blade outline without midrib, $\times 100 ; \mathrm{D}$, detai of leaf margin with adaxial ribs and furrows, sclerenchyma strands, vascular bundles and chlorenchyma - note the absence of a narrow pointed margin with sessile glandular cells, $\times 250$. E-F, abaxial epidermal preparations: $E$, intercostal long cells with thin, slightly sinuous walls, microhair basal cells and absence of stomata, $\times 250 ; \mathrm{F}$, long cells with sinuous walls, microhairs, stomatal absence and nodular silica bodies, $\times 400$. G-H, examples of specimens from the Struisbaai population: G, leaf outline illustrating infolded nature of blade and well developed adaxial sclerenchyma strands, $\times 250$; $\mathrm{H}$, abaxial epidermis with sinuous long cell walls, microhairs, no stomata and variable, nodular silica bodies, $\times 250$. A, B, E, Ellis 5435; C,F, Ellis 5433; D, Ellis 5434; G, H, Davidse 34053. 
tend to be inflated. Abaxial epidermal cells: bulliform cells absent; similar in size to adaxial epidermal cells but all cells of uniform size; cuticle thin; no epidermal appendages present. Slightly enlarged sessile glandular cells present in the extreme margin in $P$. dentatum and $P$. ecklonii but absent in $P$. pholiuroides (Figures $1 \mathrm{~B} ; 2 \mathrm{C}$ ); probably constitute part of marginal linear glands which appear to vary from 3-7 cells wide and are located on a distinctly narrow and projecting margin. These structures are also visible in surface view (Figure $1 \mathrm{G}, \mathrm{H}$ ) where the persistent nuclei are clearly visible.

\section{Abaxial epidermis in surface view}

Intercostal long cells: elongate, rectangular (Figures $1 \mathrm{~F}$, $\mathrm{H} ; 2 \mathrm{D}, \mathrm{E} ; 3 \mathrm{H}$ ) to fusiform (Figures $1 \mathrm{E}, \mathrm{G} ; 3 \mathrm{E}, \mathrm{F}$ ); walls virtually straight to moderately or deeply sinuous (Figure $4 \mathrm{~A}, \mathrm{C}, \mathrm{E}$ ); end walls vertical; walls unthickened to slightly thickened. Cell shape and size consistent across intercostal zones; long cells adjoin one another or separated by short cells; no bulliform cells. Stomata: usually absent in $P$. pholiuroides (Figure 3E, F, H) but present in $P$. dentatum and $P$. ecklonii (Figures $1 \mathrm{E}-\mathrm{H} ; 2 \mathrm{D}, \mathrm{E}$ ); low dome-shaped to dome-shaped subsidiary cells; $1-3$ rows of stomata per intercostal zone; 1 elongate, rectangular interstomatal cell separates individual stomata in a file. Intercostal short cells: presence variable, either absent or irregularly present; when present usually paired; square to tall and narrow in shape. Papillae absent. Prickles: absent. Microhairs: present on all specimens; bicellular, but variable with basal cell either shorter than distal cell (Figures 3F; 4B, D) or the two cells equal in length (Figure 4F); hairs longer than stomatal length; distal cell deciduous and thin-walled. Macrohairs: usually absent but always present in $P$. dentatum (Figure $1 \mathrm{E}-\mathrm{H}$ ); rarely present in $P$. pholiuroides; unicellular, soft hairs with single inflated, hemispherical cell associated with the superficial base. Silica bodies: angular, irregular dumbbell-shaped to nodular; horizontally elongated; exclusively costal in very narrow ( $1-3$ files) costal zones; separated by costal short cells.

\section{DISCUSSION AND CONCLUSIONS}

\section{Differences between the species of Prionanthium}

The three species of Prionanthium can readily be distinguished from one another on anatomical criteria as summarized in Table 1. $P$. dentatum is unique in the genus in possessing macrohairs but it otherwise resembles $P$. ecklonii very closely in leaf anatomy: both species have similar outlines, ribs and furrows, abaxial stomata and microhairs. They also share the very unusual marginal, sessile glands which are currently only known in four or five species of Pentaschistis. In addition to the macrohairs, $P$. dentatum and $P$. ecklonii also differ slightly in the arrangement of the vascular bundles and in the extent of the development of the sclerenchyma strands. $P$. dentatum and $P$. ecklonii, therefore, appear to be more closely related to each other than either is to $P$. pholiuroides. This agrees with the morphological evidence, particularly that of the glume glands where $P$. dentatum and $P$. ecklonii share similar stalked multicellular glands, whereas in $P$. pholiuroides the glands are sessile (Davidse 1988).

$P$. pholiuroides is distinct in the genus on the basis of a number of features: the leaf outline is inrolled to infolded; the adaxial furrows are narrow and cleft-like; there are fewer large vascular bundles in the leaf transection which is, consequently, narrower; the outer bundle sheath is often not entire but interrupted abaxially; the sclerenchyma strands may be conspicuous; the margin is not tapering and lacks the linear glands and abaxial stomata are absent or very rare. $P$. pholiuroides can, therefore, be readily separated from both $P$. dentatum and $P$. ecklonii on leaf anatomy and this study fully supports the recognition of these three species in the genus.

The results presented here must be interpreted with caution as only single populations of both $P$. dentatum and $P$. ecklonii were examined in this study due to the rarity of all the species. In the case of $P$. dentatum the same population was sampled on three different occasions - in the spring of 1975,1987 and 1988. All these specimens are virtually identical in leaf anatomy and very little variation was exhibited. However, two populations of $P$. pholiuroides were included in the study and they exhibit obvious anatomical variation as illustrated in Figure 3. The Mamre population has more open leaves with smaller adaxial sclerenchyma strands than the Struisbaai population. Although these differences are visually rather striking, they do not represent significant differences, and characters such as vascular bundle number and arrangement, the cleft-like furrows and the absence of abaxial stomata remain consistent. It is of relevance to note that the Struisbaai population also differed cytologically from the Mamre population in the occurrence of a small B chromosome and this population was also the most variable in spikelet morphology (Davidse 1988). Nevertheless, it appears likely that most of the anatomical features separating the species will hold even when more material becomes available.

TABLE 1.-Anatomical differences between the three species of Prionanthium

\begin{tabular}{lccc}
\hline & $P$. dentatum & $P$. ecklonii \\
\hline Outline & open, expanded & open, expanded pholiuroides \\
Adaxial furrows & shallow, open, wide & shallow, open, wide & 5 \\
No. l'vbs in section & 5 or 7 & 3 & 3 \\
No. 3'vbs between l'vbs & 2 & entire & inrolled \\
Outer bundle sheath & entire & minute & small \\
Adaxial strands & small & tapering & absent opposite phloem \\
Bulliform cells & medium & present & small or conspicuous \\
Margin in transverse section & projecting, narrow & absent \\
Marginal glands & present & absent & absent \\
Abaxial stomata & present & present & absent \\
Macrohairs & & absent
\end{tabular}




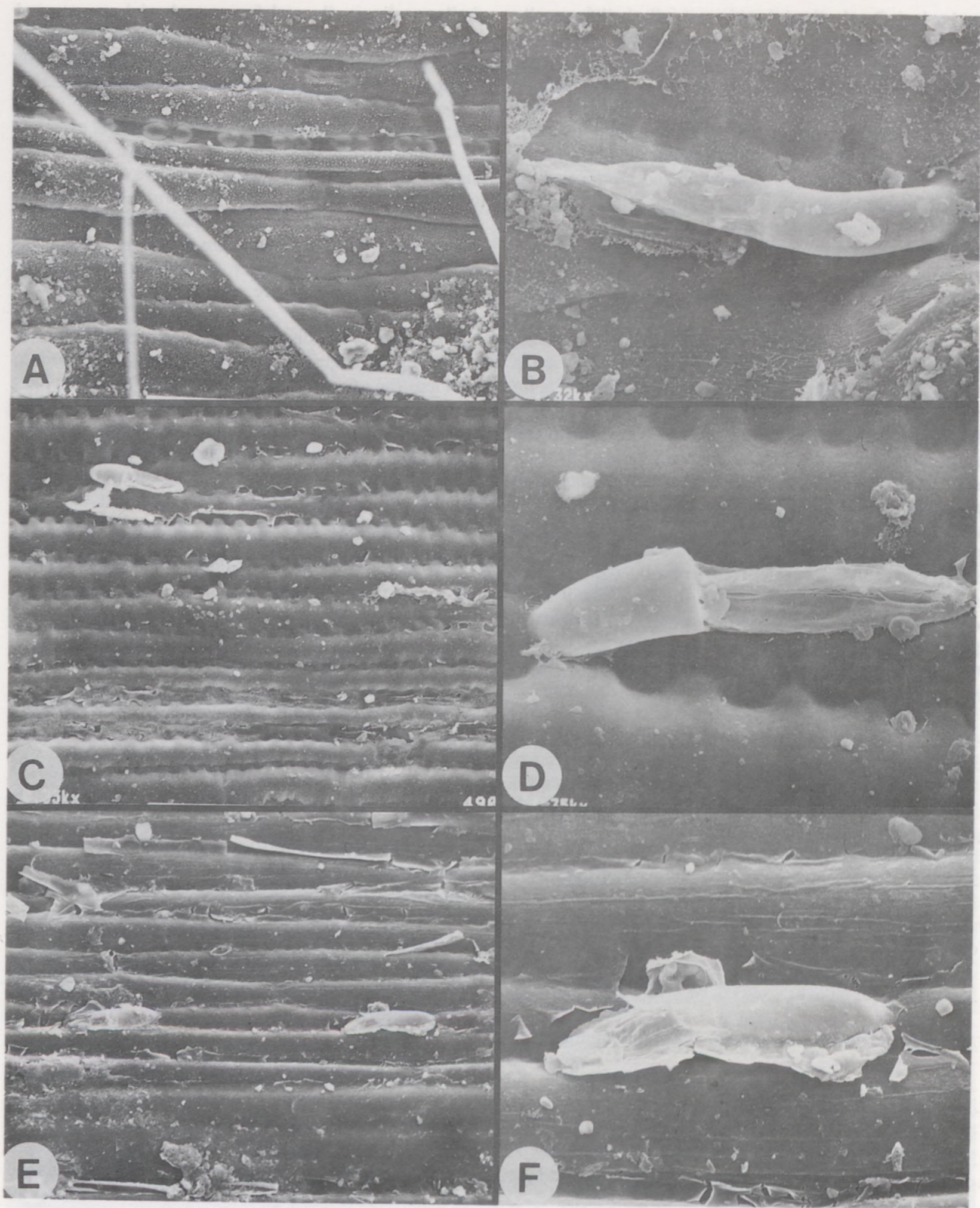

FIGURE 4.-SEM micrographs of the abaxial epidermis of different species of Prionanthium. A-B, P. dentatum, Ellis 5416: A, general epidermal features with macrohairs, stomata and inflated, slightly sinuous long cells, $\times 204$; B, bicellular microhair with tapering distal cell, $\times$ 790. C-D, P. ecklonii, Davidse 34018: C, thickened, very sinuous long cells, stomata present (but not illustrated), $\times 210 ; \mathrm{D}$, bicellular microhair with distal cell longer than basal cell, $\times 810$. E-F, P. pholiuroides, Ellis 5433: E, long cells slightly inflated and walls not undulating, stomata and macrohairs absent, $\times 210 ; \mathrm{F}$, microhair with basal cell longer than distal cell, $\times 780$.

\section{Subfamilial and tribal classification}

Numerous characters of the leaf anatomy support the classification of Prionanthium in the Arundinoideae, confirming the reports of previous workers (Hansen \& Potztal 1954; De Wet 1956; Renvoize 1986; Watson et al. 1986). The anatomy is $C_{3}$ with diffuse mesophyll, a double bundle sheath and without colourless cells accompanying the bulliform cells. This structure eliminates the possibility of panicoid or chloridoid relationships and the absence of fusoid and arm cells rules out a bambusoid alliance. The presence of microhairs, dome-shaped stomata and dumbbell to nodular silica bodies are all characters which are unequivocally 
arundinoid and exclude pooid affinities. The anatomical evidence is, therefore, in full agreement with all other indications (Davidse 1988) and Prionanthium appears best placed in the Arundineae of the Arundinoideae.

Within the Arundineae the generic relationships of Prionanthium are subject to differing interpretations. Clayton \& Renvoize (1986) are of the opinion that Prionanthium, and in particular $P$. dentatum, suggests a relationship with Tribolium and the other primitive arundinoid genera. Leaf anatomical characters can be used to substantiate such a relationship, particularly as all the primitive South African arundinoid taxa display similar mesophyll characteristics - which will here be termed the orthophyllous or mesic anatomical type. This differs significantly from the sclerophyllous type found in genera such as Merxmuellera and Pentameris. These two basic arundinoid anatomical types are discussed in Ellis (1988a) and Prionanthium shares many anatomical similarities with primitive genera such as Tribolium and Urochlaena (Ellis 1988a). However, other arundinoid genera not included in the heterogeneous group of primitive genera (Clayton \& Renvoize 1986) also have this orthophyllous type of anatomy. Chaetobromus (Ellis 1988b), Schismus, Karroochloa and some species of Pentaschistis are examples and, therefore, the possession of the mesic type of arundinoid anatomy does not necessarily appear to indicate affinity.

Davidse (1988) proposes a distant relationship between Prionanthium and Pentaschistis based on several shared spikelet characters, the most important being the occurrence of well differentiated multicellular glands on the glumes of all three species of Prionanthium and on the glumes, pedicels and leaves of several species of Pentaschistis (Linder et al. in prep.). Although stalked multicellular glands do not occur on the leaves of Prionanthium, the presence of sessile, linear glands serves to strengthen the argument of affinities between these two genera.

The leaf glands do not appear to represent equivalent structures to the sessile glands of the glumes of $P$. pholiuroides which appear to be similar to the multicellular glands but lack the stalks. The sessile glands on the leaves are linear structures with the glandular tissue not aggregated into raised, cylindrical cones as is the case with the glume glands. Prionanthium is, therefore, unique in the possession of two gland types. In Pentaschistis both these gland types occur (Linder et al. in prep.) but not on the same plants or species and are characteristic of two different species groups. On the basis of this character alone Prionanthium, therefore, appears to be intermediate between the Pentaschistis species groups represented by $P$. triseta and $P$ thunbergii (Kunth) Stapf. Affinities with Pentaschistis are supported by the anatomical evidence, but a critical revision of Pentaschistis is needed before the phylogenetic links of Prionanthium become more lucid.

\section{ACKNOWLEDGEMENTS}

The co-operation and suggestions of G. Davidse contributed substantially to this paper. Mrs A. Botha is gratefully thanked for technical assistance, Mrs A. Romanowski for the photography, Mrs S. Perold for the electron microscopy and Mrs S. Brink for typing the manuscript.

\section{REFERENCES}

CHIPPINDALL, L.K.A. 1955. A guide to the identification of grasses in South Africa. In D. Meredith. The grasses and pastures of South Africa. Central News Agency. Cape Town.

CLAYTON, W.D. \& RENVOIZE. S.A. 1986. Genera graminum. Kew Bulletin Additional Series 13: 1-389.

DAVIDSE, D. 1988. A revision of the genus Prionanthium (Poaceae: Arundineae). Bothalia 18: 143-153.

DE WET, J.M.J. 1956. Leaf anatomy and phylogeny in the tribe Danthonieae. American Joumal of Botany 43: 175-182.

ELLIS, R.P. 1976. A procedure for standardizing comparative leaf anatomy in the Poaceae. I. The leaf blade as viewed in transverse section. Bothalia 12: 65-109.

ELLIS, R.P. 1979. A procedure for standardizing comparative leaf anatomy in the Poaceae. II. The epidermis as seen in surface view. Bothalia 12: 641-672.

ELLIS, R.P. 1988a. Leaf anatomy of the South African Danthonieae (Poaceae). XVI. The genus Urochlaena. Bothalia 18: 101-104.

ELLIS, R.P. 1988b. Leaf anatomy of the South African Danthonieae (Poaceae). XVII. The genus Chaetobromus. Bothalia 18: $195-209$.

HANSEN, I. \& POTZTAL, E. 1954. Beiträge zur Anatomie und Systematik der Leptureae. Botanische Jahrbücher 76: 251-270.

LINDER, H.P. THOMPSON, J.F., ELLIS, R.P. \& PEROLD, S.M. in prep. The occurrence, anatomy and systematic implications of multicellular glands in Pentaschistis and Prionanthium (Poaceae-Arundinoideae-Arundineae).

RENVOIZE, S.A. 1986. A survey of leaf anatomy in grasses VIII. Arundinoideae. Kew Bulletin 41: 323-342.

WATSON, L., DALLWITZ, M.J. \& JOHNSTON, C.R. 1986. Grass genera of the world: 728 detailed descriptions from an automated database. Australian Joumal of Botany 34: 223-230. 